\title{
THEODICY AS GOD'S PORTRAITURE
}

\begin{abstract}
The aim of this paper is to examine one of the best known and most frequently disapproved philosophical ideas: namely, theodicy. Some classical arguments formulated by Plotinus, Augustine, and Leibniz are examined. Then, Kant's harsh critique of theodicy is introduced. The main aim of our suggested reinterpretation of the classical debate is to employ a new definition of evil formulated by Richard Kearney. Having considered evil as 'something that must be actively contested', the theodicean reasoning should be reimagined. The paper will advance from the rational vindication of God's goodness and justice to the portraiture of God's active contestation of evil. The metaphysical thought of Plotinus, Augustine and Leibniz is to be redirected from its past orientation towards a future disposition. The Kantian idea of an authentic theodicy based on the Book of Job will also be introduced. This will allows us to steer firmly between the Scylla of a metaphysical overlooking of individual suffering and the Charybdis of disregarding God when facing evil.
\end{abstract}

Keywords: theodicy, evil, God, portraiture

1. Theodicy: A Definition. 2. Some Historical Examples. 3. Kant's Critique. 4. Practical Contestation. 5. God's Portraiture. 6. A New Theodicy. 7. Conclusions.

\section{THEODICY: A DEFINITION}

A marvelous plenitude of different formulations of theodicy grips one's attention when first glimpsing at the historical background of the issue. Various authors stressed various facets of the problem. The idea of God's immutability, wisdom, sovereignty, and will, as well as the ideas of human freedom and the transience of evil have all been taken under consideration. A famous definition introduced by Kant states: "By «theodicy» we understand the defense of the highest wisdom of the creator against the charge which reason brings against 
it for whatever motive is counterpurposive in the world." ${ }^{1}$ What Kant puts at stake here is the rationality of God ('wisdom', in German: die Weisheit). It goes without saying that it is a notion of rationality adjusted to human cognitive powers, which Kant expresses with the word 'reason' (in German: die Vernunft). Evil, characterized above as 'counterpurposive in the world', is a fact that cannot be understood in terms of human reasoning. It erupts into the world and makes a rupture in the rational worldly order. It violates the world's purposiveness that has been tacitly implied. In Kant's account, human reason is not only capable, but also obliged to pass verdict on that rupture. In a theodicy, God's actions will no longer be misted with an opaque cloud of transcendence. In other words, Kant understands theodicy as a rational explanation of anything that goes wrong in the world. If: (1) God has created the world; and (2) there is a flaw in it; then (3) the idea of a rational God must be rejected, unless (4) one finds a reasonable solution that is to be called theodicy. Having considered theodicy in such a way, Kant ends up saying it is impossible to bring it forward within philosophy. However, for Kant there is another option originally introduced in the Book of Job, which I will consider in later sections.

Another example of a definition of theodicy can be found in a provocative essay by Hans Jonas, titled The Concept of God after Auschwitz. Having in mind the horrific reports that brought to light the almost ineffable suffering of the innocents, Jonas has no choice but to reject classical theodicean reasoning. There are different ways of doing this. Jonas says: "seeing the existence of evil in the world, we must sacrifice intelligibility in God to the combination of the other two attributes. Only a complete unintelligible God can be said to be absolutely good and absolutely powerful, yet tolerate the world as

1 I. Kant, Religion and Rational Theology, Cambridge University Press, Cambridge - New York 1996, 24. 
it is." 2 To Jonas, such an unintelligible God is not coterminous with the God of Judaism. As a result, he ultimately stands for "the elimination of the divine omnipotence." 3 In fact, that was an act of God's selflimitation. The definition above discloses the most fundamental aim of any theodicean reasoning, which is a philosophical strategy that combines three of God's attributes (i.e. (i) intelligibility, (ii) goodness, and (iii) power) in their absolute state. What is more, given that God is understandable, merciful and mighty, he must relate to the world. Otherwise, God is only an abstract formula that is coherent, but not real. It is precisely God's accountability for the world's misery that is troublesome for each of his three absolute attributes.

\section{SOME HISTORICAL EXAMPLES}

Having presented a basic definition of theodicy, let me now confront it with some classical examples. I will summarily draw on Plotinus, Augustine, and Leibniz. Although their ideas have been extensively studied for hundreds of years, my intention is to take a step forward and after introducing their views, to read them in a new way.

It is believed that the very beginning of theodicean reasoning is in Plotinus' Enneads. The Neoplatonic thinker explores an intriguing intertwinement of the bad and the material in the world. Before getting to the bad, however, Plotinus first pays attention to the good. It is the good that all else depends on and circles around. He speaks about the good in terms of a deity, a central element in his metaphysical vision. Plotinus' metaphysics of evil can be summed up with the following syllogism: (1) Nothing but the divine good can be called being. What is more, (2) there is no evil in the good, for if there were the good would be feeble and loose its goodness. Thus, (3)

$2 \mathrm{H}$. Jonas, The Concept of God after Auschwitz: A Jewish Voice, The Journal of Religion 67(1987)1, 9.

3 Ibidem, 11. 
"Evil cannot have place among Beings or in the Beyond-Being." Nevertheless, we are constantly afflicted by the variety of bad things. It seems they exist. It seems they are beings. How does Plotinus respond to this? In the Enneads it is said that "if Evil exists at all, then it must be situated in the realm of Non-Being." 5 A paradoxical conclusion. Evil can be recognized as being in one sense: namely, as a non-being being. One could easily get confused with an entity so ambiguous and self-contradictory as a 'non-being being. Thus, in order to ground his reasoning in ordinary experience Plotinus makes haste with a popular example. He considers matter. In ancient times, due to a widely accepted Neoplatonic view, matter was considered to be a shadow, a misshaped image, a lack. There is no other thing so corrupting and destroying of the absolute being, which was equated with the good, as evil. Therefore, one can clearly conclude: "evil is an absolute lack."

Going back to the definition of theodicy as a strategy that combines three absolute attributes of God, it seems that Plotinus claims that evil cannot spoil God's intelligibility, goodness and power, because there is no existing evil at all. Evil is a non-being being. Its being is a lack of the being of the good.

In the following centuries the history of theodicy went from Plotinus to Augustine, who fleshed out Platonic and Neoplatonic ideas and adapted them to the Christian doctrine. Most of the analysis discussed above was also endorsed by the Roman thinker. However, Augustine finds the problem of matter a moot point in the debate with Greek philosophy. After a long struggle, he finally rejected the repudiation of matter in the name of the biblical doctrine of Creation.

\footnotetext{
4 Plotinus, The six Enneads translated by Stephen MacKenna and B. S. Page, William Benton, Chicago 1952, I:8:2.

5 Ibidem, I:8:3.

6 Ibidem, I:8:5.
} 
The core of Augustine's argument against evil is an ontological reasoning, which truly resembles the Plotinian account of the good. The conclusions of Augustine's argument, however, go well beyond their predecessors due to their Christian background. The author of the Confessions pondered on all the things other than God and realized that "they are neither wholly real nor wholly unreal. They are real in so far as they come from [God]; but they are unreal in so far as they are not what [God] is." 7 This idea has undoubtedly been borrowed from Plotinus or even Plato. Yet, Augustine does not say that a non-good being is a non-being being. There is an embryo of goodness in everything in the world. Even the Devil has preserved a residue of his angelic nature. Otherwise, he would be a sheer counterpart to God and Augustine's account would look like a Gnostic-Manichean view. Augustine supplements philosophical speculation with the religious idea of the prodigal son.

Considering the bad things, Augustine says: "If they are deprived of all good, they will cease to be. So long as they are, therefore, they are good. Therefore, whatsoever is, is good. Evil, then, the origin of which I had been seeking, has no substance at all." ${ }^{8}$ The Confessions arrive at essentially the same conclusion as the Enneads. Still, the former work is considerably more careful when it comes to condemning the bad in the world, whereas the Enneads disregard it openly. This difference is due to the Christian idea of contingently renewing, enhancing and christening the corrupted world of matter. Christ's incarnation redeems matter. Christianity speaks against the Platonic or Orphic departing from it.

For the same reason Augustine introduces into the debate on theodicy a new argument, i.e. the harmony of the universe. He expands on the idea of the non-substantial, spectral nature of evil. The badness of evil could be found to be an illusion, when we look at

7 Augustine, Confessions, Hendrickson Publishers Marketing, Peabody 2011, 129 (VII:11).

8 Ibidem, 130 (VII:12). 
the bigger picture. Augustine says: "But in the parts of creation, some things, because they do not harmonize with others, are considered evil. Yet those same things harmonize with others and are good, and in themselves are good." 9 The point here is that the impression of evil has its origin in a limited view of the highly complex whole. Each supposedly bad thing is to be replenished by the specific part of the creation that makes it valuable and reasonable. There are beasts and cattle, both needed in the food chain. Sunny days and stormy rains have been equally allowed by the Creator for climate sustainability. Not everybody will come to terms with the Augustinian argument. One needs to think here about Voltaire's account of the Lisbon earthquake, Fyodor Dostoyevsky's deep look into a raped girl's eyes or Hans Jonas' expression of grief after the horror of Auschwitz. What kind of benefit could justify the torments of the innocents? The only answer that Augustine could give was that suffering occurred as a justified punishment for sin in its most fundamental dimension: the original sin.

To sum up: in Augustine, as in Plotinus, evil has been deprived of the strong status of being. Evil, however, has not yet slipped into the dark abyss of nothingness or non-existence. For Augustine, there still is the possibility to transform it and save it through Christ. What is more, he says that evil is a human misperception of the harmonized world. There is no blame on the Creator. On the contrary, there is a double human fault: a moral one for the terrible deeds which destroyed the originally perfect creation and a cognitive one for overlooking the harmony in the world.

When tracing the history of the debate on theodicy, one can single out Gottfried Wilhelm Leibniz. The German thinker explores the Augustinian idea of harmony. However, by going much further than Augustine he makes it more radical and draws far-reaching conclusions. In Essays on the Goodness of God, the Freedom of Man and

9 Ibidem, 130 (VII:13). 
the Origin of Evil, Leibniz accepts the principles of God's absolute wisdom and goodness. It follows from these assumptions that "this supreme wisdom, united to a goodness that is no less infinite, cannot but have chosen the best." 10 Therefore, Leibniz contends, the world we live in is the best possible one. Yet, all the bad things in the world seem to run against the allegedly best option chosen by the supreme wisdom. Could he not choose a better world? Could he not exclude from his creation suffering, distress and the misery of human life? In other words, how does Leibniz deal with the issue of evil? In his Theodicy, he examines the mutual dependence between good and evil. Leibniz notices that "as a lesser evil is a kind of good, even so as a lesser good is a kind of evil if it stands in the way of a greater good." 11 The absoluteness of God's goodness forces God to choose the best option. Any imperfection in his creation would pose the alarming question whether it could have been done better. Maximizing the good involves including some of the bad things. Then Leibniz says: "there are innumerable ways (...) and an infinitude of possible worlds among which God must needs have chosen the best." 12 However, according to Leibniz, God's choice is absolute and perfect. Now Leibniz is approaching the core of the Augustinian argument based on the world's harmony, but his own interpretation expands on it: "it is true that one may imagine possible worlds without sin and without unhappiness (...) but these same worlds again would be very inferior to ours in goodness." 13 This reasoning exceeds the idea of Augustine. Not only can one find many good things that supplement the bad things in the world, but the bad things themselves are necessary to increase the world's goodness. Therefore suffering, pain and lament are inevitably interwoven with bliss, joy and exhilaration. Only

\footnotetext{
10 G.W.F. Leibniz, Theodicy, Routledge \& Kegan Paul, London 2008, 131 (I:8).

11 Ibidem.

12 Ibidem.

13 Ibidem, 132 (I:10).
} 
against the background of the bad can the good reach its ultimate level. Leibniz concludes: "if the smallest evil that comes to pass in the world were missing in it, it would no longer be this world; which, with nothing omitted and all allowance made, was found the best by the Creator who chose it." ${ }^{4}$ The utmost optimism permeates the philosophy of Gottfried Wilhelm Leibniz.

\section{KANT'S CRITIQUE}

The modern debate on theodicy reaches its peak in a penetrating analysis of the pros and cons written by Kant. In his short essay $O n$ the miscarriage of all philosophical trials in theodicy, the German philosopher brings forward the arguments on both sides of the dispute and eventually, as the title of his essay suggests, claims that no rational theodicy is viable. Kant says that evil violates three of God's attributes, which are not the ones considered by his predecessors. For Kant, the divine attributes in question are: (1) holiness, (2) goodness and (3) justice, rather than (i) intelligibility, (ii) goodness, and (iii) power. (1) The first attribute has been undermined by "the absolutely counterpurposive, or what cannot be condoned or desired either as end or means." 15 If there are terrible and entirely unjustifiable things in the world, one can no longer predicate holiness of God; (2) The second attribute is undermined by the 'conditionally counterpurposive'. This means that there are some bad things that will ultimately be accepted as a means of fulfilling an absolute and good aim. However, in the meantime they must be perceived as the infringement of God's goodness. (3) Finally, God's justice is threatened by the weal of the wicked and the woe of the righteous. Let me skip the third aspect of the controversy over theodicy and focus on the first two.

14 Ibidem, 132 (I:9).

15 I. Kant, op. cit., 25. 
(1.a) The most common defense against the first accusation is to say: "there is no such thing as an absolute counterpurposiveness which we take the trespassing of the pure laws of our reason to be."16 In other words, it is human perception, rather than God's wisdom, that is being discomforted by the allegedly absolute counterpurposive in the world. One can easily identify this defense with Plotinus' argument against evil based on the idea that matter was a non-being being. A non-material God could ignore evil because of its material nature. Human beings have the possibility to go beyond their carnal condition and thanks to the non-material and God-likening, reason could liberate itself from evil. However, Kant does not entirely follow the Plotinian argument in his interpretation. He cites Isaiab55.8: "My thoughts are not like your thoughts," and seems to reject Plotinus' assumption of the human rational understanding of evil as a nonbeing. A convincing interpretation of Kant's reasoning would be the following: one can understand evil as non-existing only at the price of sacrificing one's rationality. For Kant there is no way to rationally believe that 'there is no evil' without falling into the pitfalls of fideism, which would devastate the intrinsically rational nature of theodicy. Even if for God there is no evil, this is useless from the theodicean point of view. As mentioned in the Introduction, theodicy is a human (not godly) reasoning. Thus, for Kant the apology above "in which the vindication is worse than the complaint, needs no refutation; surely it can be freely given over to the detestation of every human being who has the least feeling for morality." 17

(1.b) Another way of discharging the threat posed by the absolute counterpurposive in the world formulated by Kant is to point at the "limitations of the nature of human beings, as finite." 18 For that reason, evil perpetrated by human beings could not be prevented.

16 Ibidem, 26.

17 Ibidem, 27.

18 Ibidem. 
Evil has essentially been inherited by mankind with the very gift of freedom received during its creation. There is an element of Leibnizian thinking in this. A limited human nature can be blamed for spreading evil in the world. Yet, according to Leibniz that very nature also makes a crucial contribution to increasing the amount of goodness. Therefore, its weak point, that is free will, should not have been sublated by God. However, Kant discerns here a seed of determinism. If a necessary inclination to doing bad deeds is to be found in free will, one could conclude that the bad in human nature is predetermined by the very act of creation. Hence, "the evil would thereby be justified, and, since it could not be attributed to human beings as something for which they are to be blamed, we would have to cease calling it «a moral evil»". 19

(2) The next accusation introduced by Kant concerns the 'conditional counterpurposive'. The temporal bad things are to be accepted for the sake of their ultimate completion in the good. This argument fully resembles Augustine's and Leibniz's theodicy discussed in the sections above. Kant says that "the arduous and sorrowful state in the present life must without exception precede that hoped-for superabundant blessedness." ${ }^{20}$ This, however, is nothing but pious wishing and Kant is fully aware of its philosophical limitations. Although he does not conclude it is false, he also stresses that this point "can indeed be pretended but in no way can there be insight into it." ${ }^{21}$ Despite its boastful language, theodicy has no means to convince one with the arguments of logical reasoning. Its persuasive value is solely coaxing. Although faith is accompanied by a complex motivational system, it remains a leap into the abyss of darkness and hope. One can undoubtedly argue on theological grounds that the bad in the world has a salvific meaning. Yet, no insight of pure reason has access to it.

19 Ibidem.

20 Ibidem, 28.

21 Ibidem. 


\section{PRACTICAL CONTESTATION}

A devastating critique of theodicy is not the only achievement in Kant's essay. Towards the end of it he turns his attention to the Book of Job and suggests another type of theodicy. The German philosopher makes a crucial distinction here. He differentiates between doctrinal and authentic theodicy. The former is based on a logical interpretation of God's utterance and its speculative conclusions are to be drawn by reason alone from the world and all of God's creation. The latter is, however, solely under the dominion of the Creator. As Kant puts it: "God then becomes himself the interpreter of his will as announced through creation." ${ }^{2}$ To confuse his reader, Kant claims it is God himself (not human reason!) that produces an authentic theodicy. Contrary to popular belief, one can easily find here an anti-modern strand in Kant's philosophy ${ }^{23}$. The divine provenance of theodicy is an important idea shared both by the pre-modern Church Fathers and the proto-postmodern Karl Barth, who protested against the modern subject-object epistemological paradigm. Kant, however, confines it to the realm of practical reason. According to Kant, in every human being there is "an efficacious (in German: machthabend) practical reason. (...) It can be considered as the unmediated definition and voice of God." ${ }^{4}$ The ethical response to the problem of evil, i.e. charity, hope or faith, does not originate in a human power. Its original source resides in God. This means, once again,

22 Ibidem, 31.

23 Two opposing interpretations of Kant's idea are possible. One is prone to say that God's transcendence has been reduced and sacrificed to the immanence of human action. The other argues that the human being, together with his/her moral deeds, has been enhanced and made god-like. A British philosopher and theologian, John Milbank, showing sympathy for the former interpretation, says there is a question whether modernity means ,to naturalize the supernatural' or ,to supernaturalize the natural'. In my view it is the latter option which is more viable. See: J. Milbank, Theology and Social Theory: Beyond the Secular Reason, Basil Blackwell, Oxford and Cambridge (MA) 1999, 207.

24 I. Kant, op. cit., 31. 
that philosophical speculation cannot challenge the problem of evil. This is only achieved through action and practical understanding. The philosopher's answer to the aporetic image of the perfect God facing the imperfection of his world is a call to bold human action. Job's trust and fidelity can be interpreted as a practical theodicy. In Kant's view the biblical figure of Job represents the superiority of the authentic theodicy over the doctrinal one.

Kant's conclusions have been eagerly accepted and implemented in contemporary philosophy. Richard Kearney finds Kant's paradigm "an ability to transfer the aporia from the sphere of theory (theoria) (...) to the sphere of a more practical art of understanding (techne/ praxis)." 25 For that reason, Kearney introduces a new definition of evil: "evil is something that must be actively contested." 26 This gives philosophy a great asset and ethics is no longer burdened with a metaphysical inquiry concerning the roots, sources and reasons of past evils. Ethics is instead oriented towards the future. It invests all its efforts into preventing evil-to-come. This, however, does not mean one needs to abandon philosophy in favour of practicing mercy in the world. What Kearney, after Kant, Ricoeur, Taylor, and (last, but not least) Aristotle, aims to achieve is 'phronetic understanding'. This is where "narrative and interpretation have their proper place, in contrast to purely theoretical reason which is the domain of science proper"27. The point of 'phronetic understanding' is to tell the history of evil. Kearney underscores its personal dimension. The history of evil makes it subjective. It binds the great metaphysical questions with an individual human fate. Any philosophical investigation gets its reward only in its practical implementation in a personal experience. Metaphysical speculation cannot satisfy the dramatic question of Job:

25 R. Kearney, Strangers, Gods and Monsters. Interpreting Otherness, Routledge, London 2009, 101.

26 Ibidem.

27 Ibidem, 102. 
'why me?', with a particular emphasis on one's personal experience. This is what Ricoeur stressed in his brilliant essay Evil: A challenge to philosophy and theology ${ }^{28}$. Kearney, following Ricoeur, describes 'working-through' (in Freud's idiom: durcharbeiten) and pardon as the apt strategies for giving cathartic answers to the problem of evil.

\section{GOD'S PORTRAITURE}

At this stage, it is worthwhile to ask how the new definition of evil makes us revisit the classical dispute on theodicy. (1) The first point has already been made by Kant. In no way could the metaphysical tradition meet the requirements that theodicy originally set up. In a nutshell: the personal dimension of the affliction caused by evil rejects any universal application. (2) The second point is my own contribution to the debate. The idea is that the traditional theodicy needs to be understood as God's portraiture.

The grammatical ambiguity of this expression is not coincidental. An analogy with the Latin genetivus subjectivus and genetivus objectivus forms can be usefully employed here. Theodicy as God's portraiture has to include both of these dimensions. To say theodicy is God's portraiture means to hold that God is both the object and the subject of it. (2a) In the first case, theodicy is a descriptive attribution of intelligibility, goodness, and power in the absolute abundance ascribed to God by humans. However, contrary to classical metaphysics the superiority of God's features has not yet been conclusively established. It depends on the active contestation of evil that humans will articulate in the future. (2b) In the second case, due to Kant's idea introduced above the attribution of intelligibility, goodness, and power is of divine (rather than human) origin. To put it another way, portraiture is the depiction of an object made by

28 P. Ricoeur, Evil, a Challenge to Philosophy and Theology, Journal of the American Academy of Religion 53(1985)4, 644. 
the artistic subject. However, regardless how non-realistic the vision is, there still remains an undoubted influence of the object, which dictates the structure of the representation. What is more, the divine origin of the practical attribution of God's perfect features is actually doing away with the gnostic threat. Since the early formulations of theodicy, its proponents felt obliged to defend God's absolute intelligibility, goodness, and power because of the concurrent gnostic worldview. Had God not been originally ascribed his perfection, there would be another metaphysical principle in the world. Thus, God has a negative counterpart that limits and endangers his divinity. In religious traditions, God's negative counterpart is called a Demon. In modern humanism, it is often found to be a human being. Now, the junction of Kant's idea of an authentic theodicy and Kearney's new definition of evil opposes both the absolute metaphysical attribution with no room left for active contestation and the gnostic threat. On the one hand, there is no absolute metaphysical attribution because the final prevailing of goodness depends on future human actions. On the other hand, according to Kant such actions still remain an 'unmediated definition and voice of God.'

There is also another facet of the subjectivity of theodicy. Surprisingly to the followers of the classical debate concerning Plotinus, Augustine or Leibniz, the postmodern thinkers are stretching out the original understanding of the notion of theodicy. Graham Ward suggests that postmodern thinkers "propose that the narratives by which our experience of the world is made meaningful (...) are all forms of theodicy." ${ }^{29}$ This claim is obviously in line with a Kantian understanding of theodicy. If one assumes that Kant makes theodicy a rational explanation of anything that goes wrong in the world, it follows that any narrative search for the general meaning and cohesion of the world is a theodicy. Making the world meaningful is

29 G. Ward, Barth and Postmodernism, New Blackfriars 877(1993), 555. 
primarily to mend the breach that evil, with its pain and wickedness, has caused.

\section{A NEW THEODICY}

Having in mind the idea of portraiture, let us take a closer look at the classical examples of theodicy introduced in the previous sections. Each of the proponents of a theodicy mentioned above should be reinterpreted in order to find their proper place in practical philosophy and 'phronetic understanding'.

What is then the practical dimension of Plotinus' theodicy? One needs to rely here on the metaphysical idea of the intertwining of being and goodness. However, these two notions are to be seen in a new way. Plotinus' abstract reasoning and its paradoxical conclusions would be found appalling by the innocent victims of evil. Those shackled in anguish would never find consolation in philosophical advice based on the privation of goodness and the deception of cognition, which they would find enraging and deceitful instead. Nevertheless, if the origins of evil reside in the impenetrable mists of the past, as argued by Kant and Kearney, Plotinus' wisdom, despite its being rooted in the past, should be projected into the future. The only viable option is to contest and counteract the evil-to-come. If the future is to come, it has to mean fulfilling goodness in the world. There would be no future for us if its coming were to be based on evil. A non-good future is not a future at all. This follows from Plotinus' view that only goodness can be equated with being. A non-good being is a non-being being. What is more, personal existence is also essentially dependent on the good. Solving ethical dilemmas, I can easily reject the good and slip into the lurking abyss of evil. This however endangers my genuine existence. It makes me a lesser being, and ultimately a non-being being again. One can also reinterpret Plotinus' disregard for matter in the light of 'phronetic understanding'. However, one needs to be clear about this. There is no point in literally fighting the material 
world. My aim is neither to support a radical strand of solipsism, nor to defend a theory of an immaterial mind. Rather, I want to resume the ancient philosophical tradition of confronting the active will of spirit with the passive determinism of matter. The theodicy of Plotinus, which is removed from past-oriented metaphysics and cast into the future, is the philosophy of will. If the intensity of my pure existence hinges on my good actions, then the act of being must be grounded upon a strong potency within me. The contingent answers to the evil-to-come are anchored in my free will and the ability to contest. Free will is, however, not a necessary presupposition to arrive at the proper theory of evil. Rather, it is ascribed to me in 'phronetic understanding'. In the very act of facing evil I recognize it as 'something that must be actively contested'. But where is God, then? In what way does the new theodicean reasoning pertain to God? The key here is to make full use of the Kantian understanding of an authentic theodicy. In actively contesting evil, and thus intensifying my being by extending the range of goodness, God's picture is to be discerned. To focus on the good of the future means to point towards God. It means to resemble his absolute goodness and perfect being.

The same strategy could obviously be employed in the case of Augustine's theodicy. Plotinus' theodicy was extended and strengthened by Augustine with the idea of the great world harmony. In Augustine's view all the bad things have been synchronized with the good things. Apparently, the misery of our world and life has been completed with a greater good that gives solid reasons for understanding evil. Nevertheless, as it was said before this type of reasoning seems unacceptable to the innocent victims of abominable Auschwitz or Kolyma. Its ontological boldness and uncompromised definitiveness demean individual suffering and the moral despair that accompanies the victims' pain. However, the idea of the great harmony, stripped of its metaphysical arrogance, is to be found plausible in a future perspective. Augustine believes that "the Omnipotent God (...) would not allow any evil in his works, 
unless in his omnipotence and goodness, as the Supreme Good, he is able to bring forth good out of evil." 30 The point here is that in the matter of evil the last word has not been said yet. After Augustine, one can reiterate that each bad thing has its good counterpart only on condition that one will personally do one's best to promote the good in the world. Without personal engagement, dedication and action the great world's harmony remains a fallacious testimony. Considering the most radical example of the Holocaust, one can bring to the fore the words of Etty Hillesum: "You (God) cannot help us, but we must help you and defend Your dwelling place inside us to the last." ${ }^{31}$ She truly believed that even the most atrocious deeds of Nazi persecutors could be overcome by her individual commitment to goodness and love. One can undoubtedly discern God's portraiture in the figure of a powerless girl challenging the horror of war and genocide with the practice of goodness. A genuine theodicy shines through her dauntless thoughts and actions. It is also important to recall Augustine's appreciation of matter here. With Plotinus' condemnation of matter the significance of will has been discovered. Augustine, instead, gives matter its limited, but deserved place once again. The power of will is not unrestricted. The epitome of Etty Hillesum makes this clear. She could not stop the extermination policies and eventually met her tragic fate. This, however, did not mean she rejected her life conditions. On the contrary, the genocidal reality was for her a call to practice goodness in the world. She recognized evil as something that must be actively contested.

The most difficult task is to find a new, phronetic meaning in the theodicy of Leibniz. The Leibnizian account is deeply rooted in the past. His search for the best possible world created by the

30 Augustine, Enchiridioni On Faith, Hope, and Love, Newly translated and edited by Albert C. Outler, Newman Press, Westminster 1955, 3:11.

31 E. Hillesum, An Interrupted Life, Owl Books, New York 1996, 176. Kearney analyzes the Etty Hillesum case in his The God Who May Be. See: R. Kearney, The God Who May Be: A Hermeneutics of Religion, Indiana University Press, Bloomington 2001, 101. 
almighty God is based upon his metaphysical orientation towards the absolute completeness. The world's great harmony has already been meticulously established. There is no serious need for Kearney's definition, if the world has originally been designed to alleviate all the bad things with greater goods. Pace, Leibniz eschews a deterministic worldview that permeates other great metaphysical systems (Spinoza's system in its most radical form). This, however, does not infringe God's definite victory over evil in the world. Human actions and reasoning are important for their salvific value, but not to implement the divine triumph. According to Leibniz, one rejects evil to save one's soul and not to contribute to God's struggle. The only plausible way to modify the theodicy of Leibniz and find a new meaning in it attuned to Kant's and Kearney's accounts is to root it out of its metaphysical dedication to the past. The perspective of the best possible world must be projected into the future. Once again, this means that the flourishing of goodness will come together with the active human contestation of evil. Moreover, the idea of the best possible world to be realized in the future reinvigorates the old religious tradition of messianism. Our particular causes are destined to save the world from evil. In the Christian worldview, their climax is to be found in the figure of Christ. Therefore, Kant's idea of an authentic theodicy could be understood as faithfully following the Messiah on behalf of practical reason.

\section{CONCLUSIONS}

Equating practical reason with an authentic theodicy is a rescue kit for the philosophical idea of theodicy, which was undermined by Kant's systematic critique. There are five main advantages to this understanding of theodicy. (1) Theodicy is no longer biased with the kind of metaphysical reasoning rejected by Kant in his essay. (2) Theodicy is no longer rooted in the past, and one can easily project its strength into the future. (3) This transforms theodicy from 
a theory into a 'phronetic understanding' of evil. (4) As a result, the new type of theodicy does not overlook individual suffering. Rather, it fully embraces the tragic and painful fate of individuals facing evil. (5) Finally, the authentic theodicy of Job and Etty Hillesum still leaves room for God. The shattering of metaphysical reasoning is not tantamount to doing away with God in the philosophical picture. Theodicy becomes God's picture painted both by humans and by God himself.

Nevertheless, the new type of theodicy has its own weak points that one needs to consider with caution or even with dismay. Some alarming questions should be asked in particular: if following the advice of practical reason means listening to 'the unmediated voice of God', does any contestation of evil fulfill God's will? What should we say about the Grand Inquisitor's falling prey to the temptation of resisting evil with cruelty and madness? The new type of theodicy requires exploring its deep phronetic understanding. Some further rules produced by practical reason are needed. Their final formulation, however, could be a moot point in the practical theodicy debate.

\section{REFERENCES}

Augustine, Confessions, Hendrickson Publishers Marketing, Peabody 2011.

Augustine, Enchiridioni On Faith, Hope, and Love. Newly translated and edited by Albert C. Outler, Newman Press, Westminster 1955.

Hillesum E., An Interrupted Life, Owl Books, New York 1996.

Jonas H., The Concept of God after Auschwitz: A Jewish Voice, The Journal of Religion 67(1987)1, 1-13.

Kant I., Religion and Rational Theology, Cambridge University Press, Cambridge New York 1996.

Kearney R., Strangers, Gods and Monsters. Interpreting otherness, Routledge, London 2009.

Kearney R., The God Who May Be: A Hermeneutics of Religion, Indiana University Press, Bloomington 2001.

Leibniz G.W.F., Theodicy, Routledge \& Kegan Paul, London 2008. 
Milbank J., Theology and Social Theory: Beyond the Secular Reason, Basil Blackwel1, Oxford - Cambridge 1999.

Plotinus, The six Enneads translated by Stephen MacKenna and B. S. Page, William. Benton, Chicago 1952.

Ricoeur P., Evil, a Challenge to Philosophy and Theology, Journal of the American Academy of Religion 53(1985)4, 635-648.

Ward G., Barth and Postmodernism, New Blackfriars 877(1993), 550-556.

MıŁosz PuczYDŁowskı

milosz.puczydlowski@up.krakow.pl

Uniwersytet Pedagogiczny w Krakowie, Wydział Humanistyczny, Instytut Filozofii i Socjologii

Podchorążych 2, 30-084 Kraków

DOI: 10.21697/spch.2019.55.1.02 